\title{
Does sustainability reporting improve financial and non financial performance in Indonesia Companies?
}

\author{
Endah Tri Wahyuningtyas ${ }^{1, *}$, Dina Anggraeni Susesti ${ }^{2}$, Muis Murtadho $^{3}$
}

\author{
${ }^{1,2}$ Department of Accounting, Faculty of Economic Business and Technology Digital, Universitas Nahdlatul Ulama Surabaya, \\ Indonesia \\ ${ }^{3}$ Department of Management, Faculty of Economic, Universitas Widya Kartika, Indonesia \\ *Corresponding author. Email: endahtri@unusa.ac.id
}

\begin{abstract}
Responsibility disclosure of a company is very important for implementing government regulations and public demands related to the disclosure of the company's sustainability in terms of economic, social, environmental which has a major impact on the company's performance in terms of both financial and non-financial. This study aims to examine the impact of sustainability reporting on financial and non financial performance of PROPER companies in Indonesia. The sample used in this study is The sample used in this study were companies which won green industry award that is listed on the Indonesian stock exchange and has published a sustainability reporting in 2015-2020. The secondary data used was taken from financial reports and sustainability reporting in 2015-2020. From this study, it showed that the economic variable has a significant positive effect on financial performance and an insignificant effect on the market and operational performance. Sustainability reports that can be seen from social, economic, and environmental factors are For example, the case of hot mudflow which was caused by Lapindo Brantas Inc., an oil and gas company. Sustainability Reporting Exposure is growing.sustainability report as measured by economics had a positive and significant effect on Tobin's Q, while the social, environmental variables on market performance and company operations affected but it was not significant. While total assets have a significant negative effect on financial performance as measured by Tobin's Q, but have no significant effect on market performance and company operations as measured by MBR and ROA. Leverage has a significant negative effect on ROA but has no significant effect on MBR and Tobin's Q.
\end{abstract}

Keywords: sustainability reporting, financial performance, market to book ratio, tobin's $q$

\section{INTRODUCTION}

In 2020, the pandemic situation has contributed to the economic and environmental decline. Energy efficiency efforts have decreased from the previous year. Efforts to reduce, reuse and recycle $\mathrm{B} 3$ and non-B3 waste also decreased by $7.62 \%$ and $49.33 \%$, respectively. The number of companies which were late in submitting financial reports to the stock exchange authority is one indicator that the company is experiencing problems within the company. The delay in financial reports has a major impact on the company's reputation regarding how much the company implements the principles of GCG. Many companies in Indonesia have been penalized for late reporting, the penalties were very diverse, ranging from written warnings, fines to business restrictions and even revocation of business licenses.

Sustainability reporting for companies is useful for publishing information that reflects organizational performance in economic, social, and environmental dimensions (Zeng \& Hengsadeekul, 2020). In the current era of globalization, stakeholders do not only look at the company's performance from financial performance (Buallay, 2020). Stakeholders also look from the side of non-financial performance such as environmental and social. Social and environmental events that occur in several companies today are also triggers for stakeholder guidance (Zeng \& Hengsadeekul, 2020). For example, the case of hot mudflow which was caused by Lapindo Brantas Inc., an oil and gas company. Sustainability Reporting Exposure is growing.

Sustainability reporting is also understood to be able to provide answers to stakeholders' requests for company performance and management performance (Buallay, 2018). The company's stakeholders consist of shareholders, government, customers, employees, and the general public. Disclosure of information greatly affects investor confidence in the prospects for the company's performance in the future which can create great expectations for the public to participate in investing in the company so that they can participate in owning the company. This study aims to analyze and prove that sustainability reporting has a positive impact on financial and non-financial performance in mining companies that are active in the company's work rating assessment program (PROPER) which are listed on the Indonesia Stock Exchange in 2015 - 2020. This is what makes. This study is different from previous research where there are many studies on sustainability reports with company 
financial performance (Al-dhaimesh, 2019; Goel \& Misra, 2017; Munshia \& Duttab, 2016; Saini \& Singhania, 2019; Tarigan \& Semuel, 2015). However, this study examines the effect of sustainability reports on financial performance, operational performance and market performance of companies during the period before the pandemic and during the pandemic.

To be able to analyze the closing price of the shares, the company under study must be listed on the Indonesia Stock Exchange so that its shares can be sold to the public. The selection of mining companies that participate in PROPER is because mining companies are required to have a high sense of environmental care as a result of the operational activities of mining companies. By following PROPER mining companies are encouraged to to be ecological understanding, improve resource efficiency, reduce environmental impact and be more responsible to employees and the surrounding community. The company is expected to be able to integrate disaster risk analysis, social and environmental vulnerability to develop its business sustainability strategy.

In Indonesia, sustainability reporting is regulated by Law no. 40 of 2007 concerning Limited Liability Companies Article 74 explains that individuals whose business activities are in the field and or related to natural resources are obliged to carry out social and environmental responsibilities (Shakil, 2021). Capital market supervisory agencies and financial institutions also issue similar regulations in regulation Number X.K.6. It can be said that the government shows the government's seriousness and concern regarding social and environmental responsibilities in the business world. However, to disclose economic, environmental, and social responsibilities is still filantropi (Hardiningsih et al., 2020). The company's financial performance is defined as a determinant of certain measures that can measure the success of a company to generate profits (Lee et al., 2014).

Reports of financial performance are made to describe the company's financial condition in the past to see the financial situation in the future (Beretta et al., 2019). If the financial statements from time to time show good and consistent results, it can be said that the condition of the company's financial performance is considered good (Aureli et al., 2020). Financial performance can be seen from financial ratios which include asset management, profitability, leverage, liquidity, and market (Al-dhaimesh, 2019). The problem and objective of this research are how is the effect of sustainability reporting on economic, environmental, and social aspects on the financial and non-financial performance of PROPER companies in Indonesia?

Research questions:

H1a. Disclosure of economic information increases the positive effect on company's financial performance

H1b. Disclosure of social information increases the positive effect on company's financial performance

H1c. Disclosure of environmental information increases the positive effect on company's financial performance

H1d. Disclosure of sustainability reporting increases the positive effect on company's financial performance
H2a. Disclosure of economic information increases the positive effect on non-financial performance of the company

$\mathrm{H} 2 \mathrm{~b}$. Disclosure of social information increases the positive effect on non-financial performance of the company

H2c. Disclosure of environmental information increases the positive effect on non-financial performance of the company

H2d. Disclosure of sustainability reporting increases the positive effect on non-financial performance of the company

\section{THEORETICAL BACKGROUND}

Institutional theory focuses on the role of systems in influencing the economic, social and environmental performance of an organization. This indicates that regulatory agencies, governments and social institutions encourage companies towards the adoption of sustainability practices and disclosure of sustainability. Signal theory focuses on the voluntary disclosure of sustainability performance information to eliminate the information asymmetry that arises between management and company stakeholders. Laskar (2018) stated that comprehensive disclosure of economic, social and environmental performance means that there is a superior commitment from the company to sustainability to stakeholders. The effectiveness of the signal itself depends on the quality and level of information disclosed in the sustainability report (Eichholtz et al., 2019; Hummel \& Schlick, 2016).

\section{DATA AND RESEARCH METHODOLOGY}

This study tries to examine whether sustainable reports improve the financial performance of mining companies on the BEI, the research approach used in this study is quantitative where this study will examine the effect of the independent variable on the dependent variable. sustainability reporting as measured by Economic, Social, Environment can improve company performance and company value. The sample used in this study were companies which won green industry award that is listed on the Indonesian stock exchange and has published a sustainability reporting in 2015-2020.

The mining companies are active on the IDX and carry out a company performance rating assessment program or (PROPER) Decree of the Minister of Environment and Forestry Number

SK.460/MENLHK/SETJEN/KUM.1/12/2020 concerning the Results of the Assessment of Company Performance Ratings in Environmental Management in 2019-2020. The data used in this study is secondary data, taken from financial reports and sustainability reporting in 2015-2020. The sample were 15 mining companies. There were 75 times of observations.

Independent Variable is sustainability reporting of company, which was measured by using the GRI standard with 3 indicators, namely economic, social and environmental social. The score for disclosure of economic, social and 
environmental information is based on the Global Reporting Initiative guidelines (Buallay, 2020). There are four main categories: Environmental Disclosure Score (EDS), Social Disclosure Score (SDS), economic disclosure score (ECDS) and SR Disclosure Score (overall combination of Environmental, Social and Economic Disclosure Score) (Buallay, 2018).

While company performance was set up as dependent variable with Market Book Ratio (MBR) as a proxy for financial performance in which MBR constitutes a marketbased measurement. In this vein, SR enables companies to maintain and to improve a robust relationships between stakeholders and the company. It also scaffolds the company to manage resources efficiently, to reduce the risk of community complaints, and to increase market capitalization (Arayssi et al., 2016; Laskar, 2018a; Naseem et al., 2017; Uwuigbe, 2018). On the other hand, MBR is a better indicator of a company's financial performance to fit and to represent the stakeholder expectations.

Non financial performance here was using operational and marketing performance. Operational performance was applied by using Return on assets (ROA). Measured of ROA use the ratio of operating profit to sales (Hussain et al., 2018; Laskar, 2018a). Meanwhile, non-financial performance used a marketing performance proxy have been measured using tobin's Q (Buallay, 2019).

Market book Ratio (Y1) as measure for financial performance: Company value as measured by market capitalization plus total debt and divided by total assets

Return On Asset (Y2) as operational performance (non financial performance) : The company's financial performance as measured by Return On Assets.

Tobin's Q (Y3) as market performance (non financial performance) : Market performance is measured based on the ratio of the company's book value

The control variables used here were the total assets and leverage (Chairani \& Siregar, 2021). Our research models are as follows :

Model (1) to test dependen financial performance :

$\mathrm{MBR}=\alpha+\beta 1 \mathrm{ECDSt}+\beta 2 \mathrm{SDSt}+\beta 3 \mathrm{EDSt}+\beta 4 \mathrm{SRt}+\beta 5 \mathrm{SIZEt}$

$$
+\beta 6 \mathrm{LEVt}+\mathrm{e}(1)
$$

Model (2 dan 3) to test dependen non financial performance

$$
\begin{aligned}
\mathrm{ROA}= & \alpha+\beta 1 \mathrm{ECDSt}+\beta 2 \mathrm{SDSt}+\beta 3 \mathrm{EDSt}+\beta 4 \mathrm{SRt}+\beta 5 \mathrm{SIZEt} \\
& +\beta 6 \mathrm{LEVt}+\mathrm{e}(2)
\end{aligned}
$$$$
\mathrm{TQ}=\alpha+\beta 1 \mathrm{ECDSt}+\beta 2 \mathrm{SDSt}+\beta 3 \mathrm{EDSt}+\beta 4 \mathrm{SRt}+\beta 5 \mathrm{SIZEt}
$$$$
+\beta 6 \mathrm{LEVt}+\mathrm{e}(3)
$$

ROA: Return on assets; MBR : Market Book Ratio ; TQ: Tobins'Q; ECDS: Economic disclosure score; SDA: Social disclosure score; EDS: Environmental disclosure score ; SR: Sustainability Reporting ; Size: Firm size (Total asset); LEV: Leverage (Debt aset ratio)

\section{RESULTS AND ANALYSIS}

Based on the test results with path analysis and we used a fixed effect model with a robust standard error clustered by firms are reported in table 1. Based on the regression results in table 1, it could be seen that the economic variable has a positive effect on Return On Assets of 0.108 and has no significant effect. The economic variable had a positive effect on the market book ratio of 0.026 and had no significant effect. The economic variable had a positive effect on Tobin's $\mathrm{q}$ of 0.395 and it was significant. Corporate innovation and corporate thinking about the future and about further development can increase the market value of companies and help them maintain or expand their stakeholder base (Buallay, 2020; Sari and Wahyuningtyas, 2020).

Furthermore, social variables had a positive effect on return on assets of 0.046 and were not significant, furthermore social variables also have a positive influence on the market book ratio of 0.004 and they were not significant, furthermore social variables had a positive influence on Tobin's q of 0.132 and were not significant. Furthermore, the effect of the environmental variable had a negative effect on return on assets of -0.313 and it was not significant, while the environment variable had a positive effect of 0.029 on the market book ratio and it was not significant, the environmental variable had a negative and insignificant effect on Tobing of -0.263 .

Table 1. Path Analysis of SR on ROA, MBR and Tobin's Q

\begin{tabular}{|c|c|c|c|c|}
\hline Variables & $\begin{array}{c}\text { Expected } \\
\text { Sign }\end{array}$ & MBR (1) & ROA (2) & $\begin{array}{c}\text { TOBIN'S } \\
\mathbf{Q}(3)\end{array}$ \\
\hline \multirow{2}{*}{ ECDS } & + & $\begin{array}{c}0,026 \\
(0,824)\end{array}$ & $\begin{array}{c}0,108 \\
(0,410)\end{array}$ & $\begin{array}{c}0,395 \\
(0,004)^{* * *}\end{array}$ \\
\hline \multirow{2}{*}{ SDS } & + & $\begin{array}{c}0,004 \\
(0,988)\end{array}$ & $\begin{array}{c}0,046 \\
(0,783)\end{array}$ & $\begin{array}{c}0,132 \\
(0,866)\end{array}$ \\
\hline \multirow{2}{*}{ EDS } & + & $\begin{array}{c}0,029 \\
(0,855)\end{array}$ & $\begin{array}{c}-0,313 \\
(0,776)\end{array}$ & $\begin{array}{c}-0,263 \\
(0,224)\end{array}$ \\
\hline \multirow{2}{*}{ SR } & + & $-0,116$ & 0,138 & 0,065 \\
& & $(0,711)$ & $(0,584)$ & $(0,825)$ \\
\hline \multirow{2}{*}{ SIZE } & & $\begin{array}{c}0,154 \\
(0,145)\end{array}$ & $\begin{array}{c}-0,096 \\
(0,213)\end{array}$ & $\begin{array}{c}-0,315 \\
(0,000) * * *\end{array}$ \\
\hline \multirow{2}{*}{ LEV } & & $-0,308$ & $-0,513$ & 0,059 \\
& & $(0,279)$ & $(0,005)^{* * *}$ & $(0,504)$ \\
\hline
\end{tabular}

The influence of the variable sustainability reporting on asset return had a positive effect of 0.138 and it was not significant, while the variable sustainability reporting had a negative and non-significant effect on the market book ratio of -0.116 , while the effect of sustainability reporting on tobis $\mathrm{q}$ had a positive and insignificant effect of 0.065 . For the influence of the control variable in this study, the first variable was size, namely TA, the TA variable had a negative and insignificant effect on return on assets of -0.096 and then the TA variable had a positive and insignificant effect on the market book ratio of 0.154 , but on the contrary with the variable TA on the Tobins $q$ variable had a negative and significant effect of 0.315 .

Furthermore, for the influence of the second control variable, namely leverage where the results of statistical calculations were known that the leverage variable had a negative and significant effect on return on assets of -0.513 while the leverage variable on the market book ratio has a negative and insignificant effect of -0.318 while the leverage variable on Tobisn $\mathrm{q}$ has a negative and insignificant effect on 
positive and not significant at 0.059 . This indicates that investors need a long time to respond to information related to economic, social and environmental issues in sustainability reporting (Chairani and Siregar, 2021; García et al, 2018).

From this study, it showed that the economic variable had a positive effect on ROA but it was not significant, where in this study the sustainability report which can be seen from social, economic and environmental factors was evidence for companies on the responsibility of disclosing social responsibility to have a positive role in increasing community satisfaction with existence of a company that can significantly improve company performance. From this study it could be seen that the disclosure of corporate sustainability in terms of economic, social, environmental and SR did not have a significant positive effect on ROA. return on assets and company growth. Al-dhaimesh (2019) also found that companies that have a commitment to sustainability reports tend to have higher financial performance as measured by ROA.

From this study it was found that economic variables had a positive and insignificant influence on the market book ratio, where disclosure of economic factors to the public provides information about the company's business potential or prospects. The economic variable had a positive effect on Tobin's q and it is significant. Disclosure of sustainable reporting is very important to show the sustainability of business processes in the future in terms of potential profits that will obtained by the company, the disclosure of social factors greatly affects the value of the company gradually, $\mathrm{SR}$, affects the subsequent market response to financial performance. The results of this study are in line with research (Karim and Rutledge, 2004) where companies that actively report their business activities will have an impact on increasing company profitability and company value. In addition, the findings revealed by (Zhao et al., 2018) state that a good corporate and social work economic can improve the company's image, so it is very important for companies to maintain the company's image because it can be considered as a promotional medium to the public. the company is responsible for the capital of some of its investors by always giving a good signal to investors by always trying to use income targeting as the basis for improving the company's performance (Primasari and Wahyuningtyas, 2020).

\section{CONCLUSION}

Disclosure of information on economic, social and environmental aspects of sustainability reporting has no significant effect on financial performance. However, the disclosure of economic information has a significant effect on non-financial performance in terms of market performance as measured by Tobin's q. This indicates the current conditions in Indonesia, if a company wants to achieve good financial performance, it can put the sustainability report as the second or third priority. Awareness and understanding regarding sustainability reports in Indonesia is still lacking even though the government has made sustainability reports mandatory.

Stakeholders in Indonesia still have not read the items reported in the sustainability report for consideration in making decisions. Therefore, suggestions for further research are better if the sustainability aspect does not only involve quantitative data, namely annual reports and sustainability reporting, but also involves other data such as the behavior of managers or owners which can be obtained through interviews or questionnaires.

We recommend that regulators pay more attention to corporate sustainability reports to ensure more transparency in the disclosure of the three aspects in sustainability reports so as to assist countries in achieving sustainable development. We suggest that financial institutions encourage companies to focus more on sustainability reporting in order to get to a better sustainability market. In addition, stakeholders must increase their knowledge regarding the importance of sustainability reporting in choosing better investments.

\section{ACKNOWLEDGMENTS}

The authors would like to thank for all my best friends who help finished this research. And the last but not a least I thank for Universitas Nahdlatul Ulama Surabaya which funded as project research.

\section{REFERENCES}

[1] Zeng, Z., \& Hengsadeekul, T. Environmental issues and social responsibility: A scientomeric analysis using citespace. Entrepreneurship and Sustainability Issues, 2020, 8(2), 1419-1436. https://doi.org/10.9770/jesi.2020.8.2(83)

[2] Buallay, A. Sustainability reporting and firm's performance: Comparative study between manufacturing and banking sectors. International Journal of Productivity and Performance Management, 2020, 69(3), 431-445. https://doi.org/10.1108/IJPPM10-2018-0371

[3] Buallay, A. Is sustainability reporting ( ESG ) associated with performance? Evidence from the European banking sector. 2018. https://doi.org/10.1108/MEQ-12-2017-0149

[4] Al-dhaimesh, O. H. The effect of sustainability accounting disclosures on financial performance: an empirical study on the Jordanian banking sector. 2019, 0-8. https://doi.org/10.21511/bbs.14(2).2019.01

[5] Arayssi, M., Dah, M., \& Jizi, M. Women on boards , sustainability reporting and firm performance.2016. https://doi.org/10.1108/SAMPJ-07-2015-0055

[6] Aureli, S., Gigli, S., Medei, R., \& Supino, E. The value relevance of environmental, social, and governance disclosure: Evidence from Dow Jones Sustainability World Index listed companies. Corporate Social Responsibility and Environmental Management, 27(1). https://doi.org/10.1002/csr.1772 
[7] Beretta, V., Demartini, C., Trucco, S., \& Internazionali, S. Does environmental, social and governance performance influence intellectual capital disclosure tone in integrated reporting? Journal of Intellectual Capital, 2019, 20(1), 100-124. https://doi.org/10.1108/JIC-02-2018-0049

[8] Chairani, C., \& Siregar, S. V. The effect of enterprise risk management on financial performance and firm value: the role of environmental, social and governance performance. Meditari Accountancy Research. 2021, https://doi.org/10.1108/MEDAR-09-2019-0549

[9] Eichholtz, P., Holtermans, R., Kok, N., \& Yönder, E. Environmental performance and the cost of debt: Evidence from commercial mortgages and REIT bonds. Journal of Banking and Finance, 2019, 102, 19-32. https://doi.org/10.1016/j.jbankfin.2019.02.015

[10] Goel, P., \& Misra, R. Sustainability Reporting in India : Exploring Sectoral Differences and Linkages with Financial

Performance. 2017. https://doi.org/10.1177/0972262917700996

[11] Hardiningsih, P., Januarti, I., Nur, E., Yuyetta, A., Srimindarti, C., \& Udin, U. The Effect of Sustainability Information Disclosure on Financial and Market Performance : Empirical Evidence from Indonesia and Malaysia. 2020, 10(2), 18-25.

[12] Hummel, K., \& Schlick, C. (2016). The relationship between sustainability performance and sustainability disclosure - Reconciling voluntary disclosure theory and legitimacy theory. Journal of Accounting and Public Policy, 35(5), 455-476. https://doi.org/10.1016/j.jaccpubpol.2016.06.001

[13] Hussain, N., Rigoni, U., \& Orij, R. P. Corporate Governance and Sustainability Performance: Analysis of Triple Bottom Line Performance. Journal of Business Ethics, 2018, 149(2). https://doi.org/10.1007/s10551-016-3099-5

[14] Laskar, N. (2018a). Impact of corporate sustainability reporting on fi $\mathrm{rm}$ performance: an empirical examination in Asia. Journal of Asia Business Studies, 12(4), 571-593. https://doi.org/10.1108/JABS-112016-0157

[15] Laskar, N. (2018b). Impact of corporate sustainability reporting on firm performance: an empirical examination in Asia. Journal of Asia Business Studies, 12(4), 571-593. https://doi.org/10.1108/JABS-112016-0157

[16] Lee, K., Cin, B. C., \& Lee, E. Y. (2014). Environmental Responsibility and Firm Performance: The Application of an Environmental, Social and Governance Model. https://doi.org/10.1002/bse. 1855

[17] Munshia, D., \& Duttab, S. (2016). Sustainability Reporting Quality of Indian and American manufacturing Firms: 2020, 11(2), 245-260. https://doi.org/10.5937/sjm11-9593
[18] Naseem, M. A., Riaz, S., Rehman, R. U., Ikram, A., \& Malik, F. Impact of board characteristics on corporate social responsibility disclosure. Journal of Applied Business Research, 2017, 33(4), 799-808. https://doi.org/10.19030/jabr.v33i4.10001

[19] Quintana-García, C., Marchante-Lara, M., \& Benavides-Chicón, C. G. Social responsibility and total quality in the hospitality industry: does gender matter? Journal of Sustainable Tourism, 2018, 26(5), 722-739. https://doi.org/10.1080/09669582.2017.1401631

[20] Saini, N., \& Singhania, M. Performance relevance of environmental and social disclosures: The role of foreign ownership. Benchmarking, 2019, 26(6), 18451873. https://doi.org/10.1108/BIJ-04-2018-0114

[21] Shakil, M. H. (2021). Environmental, social and governance performance and financial risk: Moderating role of ESG controversies and board gender diversity. Resources Policy, 72(May 2020), 102144. https://doi.org/10.1016/j.resourpol.2021.102144

[22] Tarigan, J., \& Semuel, H. (2015). Pengungkapan Sustainability Report dan Kinerja Keuangan. Jurnal Akuntansi Dan Keuangan, 16(2), 88-101. https://doi.org/10.9744/jak.16.2.88-101

[23] Uwuigbe, U. (2018). Sustainability Reporting And Firm Performance: A Bi-Directional Approach. 17(3), $1-16$.

[24] Sari, N. R., \& Wahyuningtyas, E. T. W. E. T. Studi Penerapan Green Accounting dan Pengungkapan Sustainability Reporting Terhadap Profitabilitas. In Proceedings National Conference For Ummah (NCU) 2020 (Vol. 1, No. 1).

[25] Primasari, N. S., \& Wahyuningtyas, E. T. Earning Management and Cash Holding as Window Dressing Detection Moderation to Past Financial Performance with F-Score Analysis. Paper presented at the Proceedings of the International Conference on Industrial Engineering and Operations Management, (August) Retrieved from www.scopus.com, Detroit, Michigan, USA, August 10 - 14, 2020. ISSN: 21698767 (U.S. Library of Congress).http://www.ieomsociety.org/detroit2020/ 